\title{
Caregivers' Perception of their Role in Early Childhood Development and Stimulation Programmes in the Early Childhood Development Phase within a Sub-Saharan African Context: An Integrative Review
}

\author{
*Zainab Ayob. B Occ Ther (UKZN), M Occ Ther (UKZN). http://orcid.org/0000-0002-7782-4302 \\ Occupational Therapist at KwaZulu-Natal Cerebral Palsy Association.
}

\author{
Chantal Christopher. B OT (UDW), PG Dip in HIV/AIDS Clinical Management, M.Phil. in Group Therapy \\ (UKZN). http://orcid.org/0000-0002-4959-7288 \\ Lecturer, Discipline of Occupational Therapy, College of Health Sciences, University of KwaZulu-Natal (Westville Campus), Durban, \\ South Africa.
}

\author{
Deshini Naidoo. B Occ Ther (UKZN), M Occ Ther (UKZN), PhD (UKZN). \\ http://orcid.org/0000-000 I-6276-22 IX \\ Senior Lecturer, Discipline of Occupational Therapy, College of Health Sciences, University of KwaZulu-Natal (Westville Campus), \\ Durban, South Africa.
}

\begin{abstract}
Introduction: Caregivers play an integral role in their child's development. Many caregivers from low resource communities within subSaharan countries face challenges in providing early childhood development (ECD) and stimulation. In South Africa, there are policies in place that aim to provide caregivers with child-care support and services; however, systemic factors often negatively impact the service delivery of early childhood development at a community level. This integrative review aimed to analyse, appraise, and synthesise the literature concerning the published evidence of caregivers' perception on their role in early childhood development and stimulation programmes for children within the ECD phase.

Method: The integrative review followed the five steps highlighted by Whittemore \& Knafl. The literature search was conducted by electronic searching through ScienceDirect, Taylor \& Francis, PubMed, JSTOR, Lancet, Google Scholar and Research Gate. Literature was included from 01 January 2010 to 31 December 2020, which was published in sub-Saharan Africa, on early childhood development and stimulation. A total of 22 records were included in the review. The data were qualitatively analysed through thematic analysis. The findings are presented according to the Bronfenbrenner's Ecological Systems Theory.

Findings: Findings highlight that caregivers' facilitation of early childhood development in their children is influenced by daily practices of child-care and rearing. Caregivers perceived their role as nurturing and disciplining their children. The educational aspect of child development was the role of the school/ECD facility. Among these influences are contextual factors, culture, and poverty, which impact the practices that caregivers implement during early childhood development. There are policies and stimulation programmes in place to support and assist caregivers/parents in facilitating early childhood development.

Conclusion: Caregivers' form an integral component in a child's early childhood development and stimulation. The caregiver role is impacted by several factors which include context, culture, awareness of services, knowledge on child development, stimulation and resources. There is poor implementation and knowledge of support structures, policies, and stimulation programmes at a community level. This, therefore, suggests that government departments need to advocate and promote for easier access to facilities to assist caregivers/parents further.
\end{abstract}

Keywords: Early childhood development, family support, policies, stimulation programmes, low resource contexts, stimulation.

\section{INTRODUCTION}

According to Bronfenbrenner's Ecological Systems Theory', child development occurs within the context of a system of complex 'layers' in the child's environment. The theory describes the interaction and relationships between the different systems, which therefore position the caregiver to promote early childhood development ${ }^{2}$. The four layers include the microsystem or the child's the immediate environment in which caregivers have a critical role in ensuring the child's well-being and development for optimal functioning ${ }^{3}$. The microsystem is also the level in which the child interacts with family, school, neighbourhood, and religious facilities ${ }^{4}$. Providing stimulation, care, health, and nutrition within early childhood has a significant impact on a child's further life course development, from enhanced school performance to improved adulthood outcomes $^{5}$. Caregiver responsive care may be impacted by several factors, including mental health and limited understanding of child development ${ }^{6}$.

The mesosystem comprises the stimulation programmes provided to caregivers to develop their skills to promote adequate stimulation and parenting practices ${ }^{7}$. The exosystem incorporates 
Search databases included

ScienceDirect, Taylor \& Francis,

PubMed, JSTOR, Lancet, Google

Scholar and Research Gate. Total

number of records found $(\mathrm{n})=90$
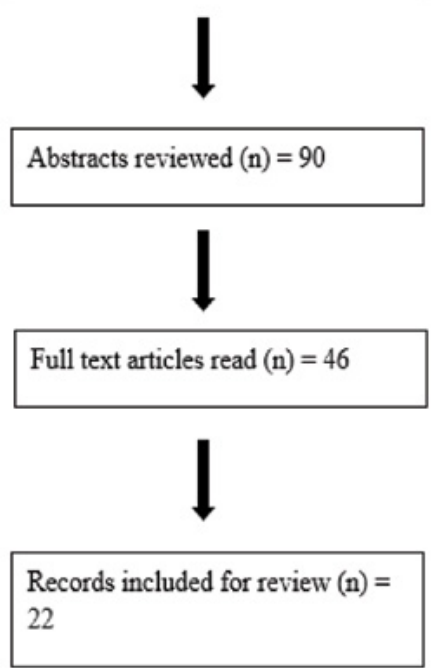

Figure I: Process of literature selection.

the influence of for example poverty, which has an indirect effect on the child ${ }^{8}$. The macrosystem contains the systemic components such as culture and policies that may be within the outermost sphere but are nuanced through to the child's development ${ }^{9}$.

South Africa has commendable policies related to early childhood development; however, there is limited implementation and measuring the outcomes of these policies, especially in low income contexts 9 . The National Integrated Plan (NIP) highlights the need to upgrade the service provision of birth-four-year-old early childhood development stimulation within the home and community setting ${ }^{10}$. Contrarily the Children's Act neglects to emphasise the importance of involving the caregiver in stimulation before formal schooling" . Therefore, South Africa requires further commitment, attention, and intersectoral planning for policy implementation to ensure effective early childhood development programmes ${ }^{12}$.

A global study conducted in 2020 on early childhood development inequalities in low/middle-income countries discovered that sub-Saharan Africa had the highest disadvantage across all child development indicators ${ }^{13}$. These indicators included exposure to risks of stunting, attending early learning facilities, home stimulation, and the progression of early child development, according to the Early Childhood Development Index (ECDI) ${ }^{13,14}$. Within South Africa, as of 20I8, $49.2 \%$ of birth to four-year-old children remained at home with their caregivers/parents with minimal stimulation conducted ${ }^{14}$. Approximately $46.8 \%$ of the children staying at home were not read to or assisted with drawing and colouring activities ${ }^{14}$. This is substantiated by another study in 2020 on early learning programme outcomes, which revealed limited caregiver engagement in stimulation, such as reading or playing with children within the home environment ${ }^{15}$.

Children within the ECD phase require stimulation for school readiness, which can be accomplished within the home environment, an early childhood facility, community programmes or through the media 16. Caregivers, particularly those from low income contexts, are faced with numerous challenges when raising a child and are often unaware of what can be done to overcome these challenges ${ }^{17}$. Occupational therapists have a role in supporting and empowering caregivers for children with or at risk for developmental delay through stimulation programmes ${ }^{18}$. The programmes may significantly impact parenting practices, caregiver-child interaction and the child's development ${ }^{19,20}$.

Despite the steps taken to improve the ECD situation in South Africa, nearly I.I million children between the ages of three to five years old have limited access to early learning and stimulation, which impacts their preparation for formal schooling $^{7}$. Steps need to be taken to improve early childhood developmental outcomes in under resourced communities. As an agent of change occupational therapists should enable those involved in ECD stimulation programmes through training, mentoring, and providing support ${ }^{21}$. Therefore, the focus of this integrative review was to explore the caregivers' perceptions on the impact of the environmental systems on early childhood development while emphasising how caregivers can be supported during the early childhood development phase in under resourced communities. Additionally, this article may assist occupational therapists in considering the evaluation of stimulation programmes when provided. This integrative review was guided by the research question: "What evidence exists on the role of caregivers in early childhood development and stimulation programmes for children within the ECD phase within low resourced communities in sub-Saharan Africa?".

\section{RESEARCH DESIGN}

The research design for this integrative review was guided by the five steps highlighted by Whittemore \& Knafl ${ }^{22}$. The steps include problem identification, literature search, data evaluation, data analysis and interpretation and representation of results. The review was conducted by the primary researcher and assisted by the research supervisors.

\section{Step I: Problem Identification}

The research question was guided by the PCC (Population, Context, Concept) framework, as per the Joanna Briggs Institute ${ }^{23}$. The population included caregivers of children within the ECD phase, the context referred to low socio-economic environments within Sub-Saharan Africa and the concept comprised of early childhood development stimulation programmes. This search was undertaken to determine the evidence of caregivers' role in the early childhood development and stimulation of children within the ECD phase.

\section{Step 2: Literature Search}

The literature search was conducted through electronic searching, of the following databases: ScienceDirect, Taylor \& Francis, PubMed, JSTOR, Lancet, Google Scholar and Research Gate. All research designs were considered. This was accessed online through the UKZN library. The database delimiters included literature from OI January 2010 to 3I December 2020, literature was inclusive of the caregiver role identification within a Sub-Saharan context and in the English language. The search string for the literature search included a combination of terms such as "caregiver and/or parent", "under-resourced areas or low socio-economic areas", or "Africa and/or Sub-Saharan Africa" together with "understanding, roles and/or perceptions of early childhood development" or "parent- 
Table I: Summary of the primary sources included in the analysis.

\begin{tabular}{|c|c|c|c|c|c|}
\hline Title & Authors & Year & Country & Method & Contribution \\
\hline $\begin{array}{l}\text { Interventions Promoting Early } \\
\text { Childhood Development in } \\
\text { South Africa }\end{array}$ & $\begin{array}{l}\text { K, Neudorf, T.R. } \\
\text { Thurman \& T.M. } \\
\text { Taylor }^{34}\end{array}$ & 2011 & South Africa & Case Study & $\begin{array}{l}\text { Promoted ECD to various stakeholders while } \\
\text { simultaneously attempting to improve current } \\
\text { ECD programme implementation across } \\
\text { multiple sectors. }\end{array}$ \\
\hline $\begin{array}{l}\text { The South African National } \\
\text { Curriculum Framework for } \\
\text { children from Birth to Four } \\
\text { Comprehensive Draft One }\end{array}$ & $\begin{array}{l}\text { H. Ebrahim \& M. } \\
\text { Irvine }^{38}\end{array}$ & 2012 & South Africa & Report & $\begin{array}{l}\text { This framework aimed to assist caregivers/ } \\
\text { parents, practitioners, and government with } \\
\text { children's care before birth to four years old. }\end{array}$ \\
\hline $\begin{array}{l}\text { Parents as partners: building } \\
\text { collaborations to support } \\
\text { the development of school } \\
\text { readiness skills in under- } \\
\text { resourced communities }\end{array}$ & $\begin{array}{l}\text { C. Pitt, R. Luger, } \\
\text { A. Bullen \& D. } \\
\text { Phillips }^{3}\end{array}$ & 2013 & South Africa & Qualitative & $\begin{array}{l}\text { Explored caregiver/parent education on } \\
\text { stimulation and home learning activities to } \\
\text { improve school readiness. }\end{array}$ \\
\hline $\begin{array}{l}\text { Early childhood development } \\
\text { services in South Africa: What } \\
\text { are the next steps? South } \\
\text { African Child Gauge } 2013\end{array}$ & $\begin{array}{l}\text { N. Albino \& L. } \\
\text { Berry }\end{array}$ & 2013 & South Africa & Report & $\begin{array}{l}\text { Emphasized the caregiver/parent-child } \\
\text { relationship and provided strategies for } \\
\text { stimulation programmes. }\end{array}$ \\
\hline $\begin{array}{l}\text { Informal settlements: informal } \\
\text { early childhood development } \\
\text { centres }\end{array}$ & $\begin{array}{l}\text { The Project } \\
\text { Preparation Trust } \\
\text { of } \mathrm{KZN}^{36}\end{array}$ & 2014 & South Africa & Report & $\begin{array}{l}\text { Reviewed literature and policies pertaining to } \\
\text { ECD centres. }\end{array}$ \\
\hline $\begin{array}{l}\text { Parent Education Programmes } \\
\text { for Early Childhood } \\
\text { Development: Reflections of } \\
\text { Practitioners }\end{array}$ & J, Baker ${ }^{17}$ & 2015 & South Africa & Mixed methods & $\begin{array}{l}\text { Explored the practitioner's reflections } \\
\text { on how stimulation programmes can be } \\
\text { improved. }\end{array}$ \\
\hline $\begin{array}{l}\text { eThekwini Municipality Early } \\
\text { Childhood Development } \\
\text { Launch }\end{array}$ & $\begin{array}{l}\text { eThekwini } \\
\text { Municipality }\end{array}$ & 2015 & South Africa & Report & $\begin{array}{l}\text { Local municipal report of improvement of } \\
\text { ECD services within a community in South } \\
\text { Africa. }\end{array}$ \\
\hline National Integrated ECD Policy & $\begin{array}{l}\text { Department } \\
\text { of Social } \\
\text { Development }{ }^{39} \\
\end{array}$ & 2015 & South Africa & Policy & $\begin{array}{l}\text { Policies in place for birth to seven years of } \\
\text { age. }\end{array}$ \\
\hline $\begin{array}{l}\text { Integrating Evidence and } \\
\text { Context to Develop a Parenting } \\
\text { Program for Low-Income } \\
\text { Families in South Africa }\end{array}$ & $\begin{array}{l}\text { J.M. Lachman, L.T. } \\
\text { Sherr, L. Cluver, } \\
\text { C.L. Ward, J. } \\
\text { Hutchings, \& F. } \\
\text { Gardner }^{27}\end{array}$ & 2016 & South Africa & Qualitative & $\begin{array}{l}\text { Focused on an intervention parenting } \\
\text { program in a low socio-economic community } \\
\text { which aimed to reduce the risk of child } \\
\text { maltreatment, improve positive parenting, } \\
\text { and reduce child behaviour problems. }\end{array}$ \\
\hline $\begin{array}{l}\text { When can parents most } \\
\text { influence their child's } \\
\text { development? Expert } \\
\text { knowledge and perceived local } \\
\text { realities }\end{array}$ & $\begin{array}{l}\text { C.M. Worthman, } \\
\text { M.Tomlinson, \& } \\
\text { M.J. Rotheram- } \\
\text { Borus }^{33}\end{array}$ & 2016 & South Africa & Qualitative & $\begin{array}{l}\text { Explored the perspectives of caregivers/ } \\
\text { parents on the opportune time to influence } \\
\text { child development. Highlighted the need } \\
\text { to educate caregivers/parents on ECD } \\
\text { importance. }\end{array}$ \\
\hline $\begin{array}{l}\text { Caring for children: } \\
\text { Relationships matter: South } \\
\text { African Child Gauge } 2017\end{array}$ & $\begin{array}{l}\text { L. Berry \& E. } \\
\text { Malek }^{31}\end{array}$ & 2017 & South Africa & Report & $\begin{array}{l}\text { Discussed the important interactions for } \\
\text { child development and the factors that } \\
\text { compromise care in South Africa. }\end{array}$ \\
\hline $\begin{array}{l}\text { Ugandan households: A study } \\
\text { of parenting practices in three } \\
\text { districts }\end{array}$ & $\begin{array}{l}\text { N. Boothby, F. } \\
\text { Mugumya, A.E. } \\
\text { Ritterbusch, J. } \\
\text { Wanican, C.A. } \\
\text { Bangirana, A.D. } \\
\text { Pizatella, S. Busi, \& } \\
\text { S. Meyer }{ }^{32}\end{array}$ & 2017 & Uganda & Qualitative & $\begin{array}{l}\text { Identified the community perspectives on } \\
\text { parenting practices. It explored caregiver } \\
\text { practices that are either harmful or promotive } \\
\text { to the child's developmental outcomes. }\end{array}$ \\
\hline $\begin{array}{l}\text { "So that his mind will open": } \\
\text { Parental perceptions of } \\
\text { early childhood education in } \\
\text { urbanising Ghana }\end{array}$ & $\begin{array}{l}\text { S. Kabay, S. Wolf, \& } \\
\text { H. Yoshikawa }\end{array}$ & 2017 & Ghana & Qualitative & $\begin{array}{l}\text { Explored parent perspectives on early } \\
\text { education for children under five years old, } \\
\text { within two communities in Ghana. }\end{array}$ \\
\hline $\begin{array}{l}\text { Effective early childhood } \\
\text { development programme } \\
\text { options meeting the needs of } \\
\text { young South African children }\end{array}$ & $\begin{array}{l}\text { L.J. van Niekerk, } \\
\text { M.A. Cooper \& E. } \\
\text { Atmore }^{9}\end{array}$ & 2017 & South Africa & Mixed methods & $\begin{array}{l}\text { Reviewed the current ECD options in South } \\
\text { Africa. This analysis provided guidelines to } \\
\text { assist policy makers in developing future } \\
\text { efficient ECD programmes. }\end{array}$ \\
\hline
\end{tabular}




\begin{tabular}{|c|c|c|c|c|c|}
\hline Title & Authors & Year & Country & Method & Contribution \\
\hline $\begin{array}{l}\text { A Feasibility RCT Evaluating } \\
\text { a Play-Informed, Caregiver- } \\
\text { Implemented, Home-Based } \\
\text { Intervention to Improve the } \\
\text { Play of Children Who Are HIV } \\
\text { Positive }\end{array}$ & $\begin{array}{l}\text { E. Ramugondo, } \\
\text { A. Ferreira, D. } \\
\text { Chung, \& R. } \\
\text { Cordier }^{35}\end{array}$ & 2018 & South Africa & $\begin{array}{l}\text { Randomised } \\
\text { control trial }\end{array}$ & $\begin{array}{l}\text { Guidelines to assist with the implementation } \\
\text { of stimulation programmes with caregivers/ } \\
\text { parents. }\end{array}$ \\
\hline $\begin{array}{l}\text { Contextualising school } \\
\text { readiness in South Africa: } \\
\text { Stakeholders' perspectives }\end{array}$ & $\begin{array}{l}\text { E. Munnik \& M. } \\
\text { Smith }^{37}\end{array}$ & 2019 & South Africa & Qualitative & $\begin{array}{l}\text { Discussed adverse experiences (in context), } \\
\text { community factors, educational factors and } \\
\text { familial factors that impact school readiness. }\end{array}$ \\
\hline $\begin{array}{l}\text { Early means early: } \\
\text { understanding popular } \\
\text { understandings of early } \\
\text { childhood development in } \\
\text { South Africa }\end{array}$ & $\begin{array}{l}\text { L.M. Richter, M. } \\
\text { Tomlinson, K. } \\
\text { Watt, X. Hunt \& } \\
\text { E.H. Lindland }{ }^{29}\end{array}$ & 2019 & South Africa & $\begin{array}{l}\text { Anthropological } \\
\text { method through } \\
\text { frameworks } \\
\text { institute }\end{array}$ & $\begin{array}{l}\text { Explored the beliefs of public members } \\
\text { and policy stakeholders regarding early } \\
\text { child development. The perceptions of the } \\
\text { stakeholders impact the steps to improve } \\
\text { ECD delivery in SA. }\end{array}$ \\
\hline $\begin{array}{l}\text { Family-based activity settings } \\
\text { of children in a low-income } \\
\text { African context }\end{array}$ & $\begin{array}{l}\text { S. Balton, } \\
\text { K. Uys \& } \\
\text { E. Alant }{ }^{25}\end{array}$ & 2019 & South Africa & Qualitative & $\begin{array}{l}\text { Explored the different activities three-five- } \\
\text { year-old engage in within the family setting } \\
\text { and the impact on child development. }\end{array}$ \\
\hline $\begin{array}{l}\text { Is Fathers' Involvement in Young } \\
\text { Children's Development and } \\
\text { Learning in the Early Years } \\
\text { Important? Experiences from } \\
\text { the Caregivers in Tanzania }\end{array}$ & $\begin{array}{l}\text { P.T. Basil \& L.G. } \\
\text { Ndijuye }^{40}\end{array}$ & 2019 & Tanzania & $\begin{array}{l}\text { Descriptive } \\
\text { exploratory } \\
\text { Design }\end{array}$ & $\begin{array}{l}\text { Paternal involvement in child well-being } \\
\text { and development of children in pre-primary } \\
\text { school. Discussed fathers' perceptions on } \\
\text { important individuals involved in childcare and } \\
\text { development. }\end{array}$ \\
\hline $\begin{array}{l}\text { Early Learning Programme } \\
\text { Outcomes Study Technical } \\
\text { Report }\end{array}$ & $\begin{array}{l}\text { A. Dawes, L. } \\
\text { Biersteker, E. } \\
\text { Girdwood, M. } \\
\text { Snelling \& J. } \\
\text { Horler }^{15}\end{array}$ & 2020 & South Africa & $\begin{array}{l}\text { Quasi } \\
\text { experimental } \\
\text { pre-test post- } \\
\text { test field study } \\
\text { design }\end{array}$ & $\begin{array}{l}\text { Comprehensively analysed early learning } \\
\text { programmes for three-five-year-old children. } \\
\text { Further explored how the home environment } \\
\text { and participation affects this. }\end{array}$ \\
\hline $\begin{array}{l}\text { "Me I don't really discuss } \\
\text { anything with them": Parent } \\
\text { and teacher perceptions of } \\
\text { early childhood education and } \\
\text { parent-teacher relationships in } \\
\text { Ghana }\end{array}$ & S. Wolf ${ }^{30}$ & 2020 & Ghana & Qualitative & $\begin{array}{l}\text { Explored early childhood education and the } \\
\text { relationships between teachers and parents o } \\
\text { pre-school children. It explores how parents } \\
\text { and teachers perceive their respective roles in } \\
\text { the child's education and learning. }\end{array}$ \\
\hline $\begin{array}{l}\text { Grandmothers' developmental } \\
\text { expectations for early childhood } \\
\text { in Botswana }\end{array}$ & $\begin{array}{l}\text { M. Tsamaase, S. } \\
\text { Harkness, C.M. } \\
\text { Super }^{28}\end{array}$ & 2020 & Botswana & Qualitative & $\begin{array}{l}\text { Urban and rural grandmothers' perception/ } \\
\text { expectations on the skills preschool child } \\
\text { should acquire. There was a significant } \\
\text { cultural component in practices. Limited } \\
\text { responses on school readiness. }\end{array}$ \\
\hline
\end{tabular}

ing practices" or "stimulation" or "stimulation programmes". The literature search produced a total of 90 records, of which 44 records were excluded after reading the abstract. The literature that did not have abstracts was reviewed to determine if the inclusion criteria was met. A further 24 records were excluded after a full review due to redundancy and not meeting the inclusion criteria.

\section{Step 3: Data Evaluation}

The literature located through the various databases were evaluated against the inclusion criteria ${ }^{22}$. The inclusion criteria consisted of published literature on early childhood development and stimulation in sub-Saharan Africa, guiding national policies, legislature documents and reports regarding early childhood development and stimulation. This included national policies, policies in KwaZuluNatal where this review supported a further study. Literature from unpublished sources, reports and documents from various organizations were considered. After the evaluation of data, a total of 22 records were selected for this study.

\section{Step 4: Data Analysis}

The data obtained from the articles were categorised according to the emerging patterns and themes, following a qualitative analysis. Using thematic analysis, the data analysis were directed by the steps highlighted by Creswell ${ }^{24}$. The data was analysed using inductive reasoning. The literature was read through multiple times to develop codes. The recurring codes were categorised into themes. Therefore, the themes were developed by an iterative process of comparing data and clustering similar information. The themes developed included caregiver engagement in early childhood development, parenting practices, parenting stimulation programmes, policies, and cultural perspectives. The analysis of data were reviewed and guided by the research supervisors, which assisted in reducing researcher bias.

\section{Step 5: Interpretation and Representation of Results} The results of the data were comprehensively reported through the integration and discussion of the themes that emerged. The findings of the review were presented in a discussion according to 
Table II: Evidence of themes correlating with the literature.

\begin{tabular}{|c|c|c|c|c|c|c|}
\hline \multirow{2}{*}{\begin{tabular}{|l} 
ECOLOGICAL SYSTEMS \\
THEMES
\end{tabular}} & \multicolumn{2}{|c|}{ Micro System } & \multirow{3}{*}{$\begin{array}{c}\text { Meso System } \\
\text { Parenting } \\
\text { stimulation } \\
\text { programmes }\end{array}$} & \multirow{3}{*}{$\begin{array}{c}\text { Exo- } \\
\text { System }\end{array}$} & \multicolumn{2}{|c|}{ Macro System } \\
\hline & \multirow{2}{*}{$\begin{array}{l}\text { Parent } \\
\text { engagement in } \\
\text { ECD }\end{array}$} & \multirow[t]{2}{*}{$\begin{array}{l}\text { Parenting } \\
\text { practices }\end{array}$} & & & Policies & $\begin{array}{l}\text { Cultural } \\
\text { practices }\end{array}$ \\
\hline ARTICLES & & & & & & \\
\hline Neudorf K, Thurman T.R \& Taylor T.M. (20II) & & & $\mathrm{X}$ & $\mathrm{X}$ & $X$ & $x$ \\
\hline Ebrahim H \& Irvine M. (20I2) & $\mathrm{x}$ & & $x$ & & $x$ & \\
\hline Pitt C, Luger R, Bullen A \& Phillips D. (2013) & & & $x$ & & & \\
\hline Albino N \& Berry L. (20I3) & & & $x$ & $x$ & $x$ & \\
\hline The Project Preparation Trust of KZN (2014) & & & & $x$ & $\mathrm{X}$ & \\
\hline Baker, J. (20I5) & & & $x$ & & & \\
\hline eThekwini Municipality (2015) & & & $x$ & & & \\
\hline Republic of South Africa (20I5) & & & & & $\mathrm{x}$ & \\
\hline $\begin{array}{l}\text { Lachman J.M, Sherr L.T, Cluver L, Ward C.L, } \\
\text { Hutchings J \& Gardner F. (2016) }\end{array}$ & $\mathrm{X}$ & $\mathrm{X}$ & $\mathrm{X}$ & & & $\mathrm{X}$ \\
\hline $\begin{array}{l}\text { Worthman C.M, Tomlinson M, Rotheram-Borus } \\
\text { M.J. (2016) }\end{array}$ & $\mathrm{X}$ & $\mathrm{X}$ & $x$ & & & $\mathrm{X}$ \\
\hline Berry L, Malek E. (20I7) & & $\mathrm{X}$ & $\mathrm{X}$ & $\mathrm{X}$ & $\mathrm{X}$ & \\
\hline $\begin{array}{l}\text { Boothby N, Mugumya F, Ritterbusch A.E, Wanican } \\
\text { J, Bangirana C.A, Pizatella A.D, Busi S \& Meyer S. } \\
\text { (20I7) }\end{array}$ & & $\mathrm{X}$ & $x$ & & & $\mathrm{X}$ \\
\hline Kabay S, Wolf S, Yoshikawa S. (20I7) & $x$ & $x$ & $x$ & & & $x$ \\
\hline Van Niekerk L.J, Cooper M. A \& Atmore E. (20I7) & & & $x$ & $\mathrm{x}$ & $\mathrm{x}$ & \\
\hline $\begin{array}{l}\text { Ramugondo E, Ferreira A, Chung D \& Cordier R. } \\
(2018)\end{array}$ & $\mathrm{X}$ & & $\mathrm{X}$ & $\mathrm{X}$ & & \\
\hline Munnik E \& Smith M. (20I9) & & $x$ & & $x$ & $\mathrm{x}$ & \\
\hline $\begin{array}{l}\text { Richter L.M, Tomlinson M, Watt K, Hunt X \& } \\
\text { Lindland E.H. (2019) }\end{array}$ & $\mathrm{x}$ & $x$ & & $\mathrm{X}$ & $x$ & \\
\hline Balton S, Uys K \& Alant E. (2019) & $x$ & $x$ & $x$ & & & $\mathrm{X}$ \\
\hline Basil P.T \& Ndijuye L.G. (2019) & $\mathrm{X}$ & $\mathrm{X}$ & & & & \\
\hline $\begin{array}{l}\text { Dawes A, Biersteker L, Girdwood E, Snelling M \& } \\
\text { Horler J. (2020) }\end{array}$ & $\mathrm{X}$ & & $x$ & $\mathrm{X}$ & & \\
\hline Wolf S. (2020) & $x$ & $x$ & $x$ & & & \\
\hline Tsamaase M, Harkness M \& Super C.M. (2020) & $\mathrm{x}$ & $x$ & & & & $\mathrm{x}$ \\
\hline
\end{tabular}

Bronfenbrenner's Ecological Systems Theory' that is the microsystem, mesosystem, exosystem, and macrosystem. This assisted in the understanding of the effect of the contributing factors of the interacting systems on the facilitation of early childhood development. This interpretation of results further assisted in providing evidence of the required adjustments to governmental service delivery and approaches to assisting caregivers of children within the ECD phase.

\section{RESULTS}

Twenty-two records that met the inclusion criteria included a study each from Uganda, Tanzania, Botswana and two from Ghana. The remainder of the studies $(n=17)$ were from South Africa. Table I (p86-87) below provides the summary of the articles selected for the review.

The six themes that emerged within the study and the evidence of themes relating to the selected literature are tabulated in Table II (p88).
Theme One: Caregiver/parent engagement in early childhood development and stimulation

The reviewed literature discussed caregiver participation, understanding, knowledge and expectations of early childhood development and stimulation. Engagement in home activities and play were not always guided by developmental agendas, rather by cultural practices from a macro level or the perceived routine within their context. Two of the studies discussed play; however, there were differing views on play, based on caregiver knowledge, culture, and contexts ${ }^{25-28}$. Caregivers perceive the child's learning and stimulation as the role of the early childhood facility attended, as opposed to the collaborative role between the caregiver and facility ${ }^{28-30}$. This perception of early childhood development and stimulation might compromise the school readiness of the child.

\section{Theme Two: Parenting practices}

Parenting practices included nurturing care, discipline, positive/ 
negative parenting, caregiver-child interaction, and parenting roles that influenced early childhood development. Negative practices were accompanied by harsh treatment, child neglect and poverty. Four of the studies indicated caregivers' duty to provide nurturing care, warmth, and love as part of their role and associated this with positive parenting practices ${ }^{17,29,31-33}$. Alternative discipline measures presented itself in some studies where corporal punishment was endorsed to promote good behaviour ${ }^{27,29,30}$. Caregiving was viewed as the mother's responsibility; however, the fathers' inclusion to assist in sharing the responsibility of caregiving and interacting in the stimulation programmes was also raised ${ }^{27}$. Furthermore, inequitable parenting roles emerged through parenting practices ${ }^{17}$.

\section{Theme Three: Parenting stimulation programmes}

Stimulation programmes are available to provide support to caregivers, promote favourable developmental outcomes and encourage appropriate parenting practices ${ }^{9,17}$. The studies that referred to stimulation programmes highlighted the significance of these programmes, provided an outline for the content and discussed the barriers and facilitators to engagement. Programme barriers included poor intersectoral collaboration, insufficient time to engage in the programmes, low socio-economic status and limited resources ${ }^{9,34}$. Programme facilitators included generalisability of programmes, family-based approach and compatibility to environmental and cultural contexts ${ }^{9,12,35}$. The content of the parenting programmes included areas in which caregivers indicated a lack of knowledge, or where researchers observed a gap of knowledge among caregivers. Prevalent topics discussed with parents included discipline strategies, nutrition, promoting maternal and child health and general stimulation activities such as traditional games ${ }^{12,17,34}$.

\section{Theme Four: Poverty}

The literature reviewed discussed increased stress levels, unemployment, perilous society and poor access to services and inequality as the outcomes of poverty, which jeopardised the child's early development and stimulation. Poverty within the low resourced context influenced access to and the services at the ECD facility in which caregivers enrolled their child. Lack of funds, further contributed to their disadvantaged position, infrastructure and the informal nature of these facilities. Despite these adverse conditions, these facilities form the central pillar of early childhood development access within low resourced communities as they provide basic needs and amenities for the children ${ }^{36}$.

\section{Theme Five: Policies}

Some policy documents covered strategies which were in place to facilitate appropriate early childhood development service provision at educational and health facilities and future early childhood development plans and guidelines to encourage access of services. In contrast, other studies indicated how policies could be shifted to facilitate a multifaceted approach that would enhance the developmental outcomes of young children ${ }^{37,38}$. Policy documents also recorded the general standards required for all ECD facilities to provide an expected service delivery level to all children ${ }^{9,36}$.

\section{Theme Six: Cultural Practices}

Cultural practices which are filtered through the microsystem and mesosystem were reported by seven studies. Cultural beliefs are nuanced through lessons of morality, respect and promoted behavioural patterns highlighted in several studies, where caregivers discussed the importance of passing on their culture and traditions ${ }^{26,28,32}$. Cultural practices are passed on in the home environment and promoted within their educational/school environment. The cultural practices further influenced how children play, what tasks were engaged in, and the expectations within their age group $^{25,26,28}$. It is therefore imperative that stimulation programmes consider culture practices, as this could indicate the success of programme compliance.

\section{DISCUSSION}

The integrative review has provided an insight into the caregivers' role in ECD, stimulation and the support available for them at different levels. This is explained through the Bronfenbrenner's Ecological Systems Theory!.

\section{Microsystem}

Thirteen of the reviewed publications discussed components within the microsystem. Respondents in selective studies indicated positive and negative parenting practices, which provided an understanding of how caregivers practices to promote or limit early child development $^{33}$. Positive practices in the Ugandan study were associated with childcare, adequate nutrition, a clean home, protection and investment in the child's education; and negative parenting was associated with opposing practices ${ }^{32}$. In one South African study, similar results were found relating to positive and negative parenting practices $^{33}$. Although promotive education factors were explored in both studies, the finer details regarding stimulation and early development in early childhood were obscured by the focus on the nurturing care and child-rearing that should take place. This was additionally observed in the limited understanding of play or activity engagement that was beneficial to the child. In a study by Balton et al. ${ }^{25}$, colouring, drawing and pasting were seen as promotive to development; however, this was assumed due to these activities being done at school. Whereas in another study, the children participated in home and self-care tasks, however this was viewed as a means to promote self-reliance, rather than promote developmental skills ${ }^{28}$. Although home and self-care tasks provide a stimulatory nature, the caregiver seems to remain unaware that this forms an integral component in caring for a child.

The childhood occupation of play was closely nuanced with cultural practices. Within the two Ghanaian studies, caregivers perceived play as a shift away from the child's learning at school and did not understand that play is educational as well ${ }^{26,30}$. Similar perceptions were detected in the study by Balton et al. study ${ }^{25}$; however, in the Lachman et al. study, the caregivers viewed play as a form of building relationships and spending time with the child; however, this was hampered by time constraints ${ }^{27}$. These varying perceptions regarding play indicate how play is conceptualised in different contexts and highlights the need to promote understanding of play which will help enhance development. The misconception of play may be due to the limited contact and collaboration with early childhood development facilities. This perception regarding play indicates the need for occupational therapists to further advocate on the importance of play and the role it has in a child's development while taking contextual factors into account.

Conflicting evidence of the caregiver role in the child's school and education was observed. Caregivers often believed this is where children learn school related skills based on their previous experience of ECD facilities. They viewed their role in collaborating with the educational facility to fulfil needs such as paying fees and provision of nutrition, and not engaging in tasks that provide stimulation for learning and developmental outcomes ${ }^{28,30}$. Teachers were also 
perceived as surrogate parents and caregivers relied on them to primarily educate their child ${ }^{37}$, resulting in a poor estimation of the child's capabilities. This could result from both limited understanding of child development and the stakeholders who have a role in the child's development. Some caregivers may have low education and have concerns about their capacity to help a child develop, which results in then relying on others to assist in the child development. This therefore highlights the need for collaboration between occupational therapists, ECD facilities and caregivers when promoting stimulation and child developmental activities.

An additional focus within parenting practice was the discipline strategies that were implemented. Some caregivers used corporal punishment to ensure good behaviour, whereas other caregivers refrained from this to reduce the damage of corporal punishment ${ }^{27}$. This perception of discipline indicates the need for educating caregivers in effective discipline strategies. Literature supports this by recommending effective discipline strategies when educating parents during parenting programmes ${ }^{17}$.

\section{Mesosystem}

Through the mesosystem, there are ECD stimulation programmes that caregivers can implement within the home environment. Implementation of stimulation programmes can assist in improving developmental outcomes by providing the child with the necessary learning and stimulation to further promote their development. Across the various studies, home-based programmes for the caregivers were recommended as it was proved to be more effective than other means of programme implementation ${ }^{9,12,34,35}$. However, a recent study contradicts this by stating a direct approach with the children is a better option, as their study revealed that caregivers did not engage in stimulatory activities due to time constraints ${ }^{15}$. These findings may impact the implementation and continuation of stimulation programmes. A family-based approach should also be implemented, as it influences the stimulation programme's maintenance ${ }^{12,35}$. Within varying socio-economic contexts, it is common for various members (adults and children) within the house to engage in childcare. Therefore, the stimulation programme should consider this approach during implementation. Should occupational therapists within under resourced communities place value on the relevant considerations to the caregivers' contexts and beliefs, it may promote eagerness and compliance with stimulation programmes provided. This in turn will assist caregivers in improving their interaction with the child and promoting better developmental outcomes.

Although there is an observable effort to implement stimulation programmes to support caregivers, several barriers hamper this effort. The barriers include lack of advocacy on early child development, inconsistent attendance of programmes due to financial constraints, limited trust in unfamiliar individuals running these programmes and poor contextual planning ${ }^{3,34,35}$. Numerous studies recommend the inclusion of contextual and cultural relevant focus, to promote stimulation within the parenting stimulation programmes, 12,17,34. Neglecting these factors may contribute to the lack of interaction and learning during the stimulation programmes ${ }^{3}$. These barriers threaten the consistent attempts at promoting a positive shift in the access to stimulation programmes and undermine the progress to improve this.

\section{Exosystem}

Poverty was acknowledged as a factor influencing the effectiveness of stimulation programmes. A plethora of studies indicated that low socio-economic status and unemployment impact the child's school readiness, stimulation, and caregiver-child activity engagement within the home environment ${ }^{15,29,35,37}$. Many policies and initiatives have guidelines to combat poverty; however, it is a larger systemic issue that requires the collaboration of multiple sectors over a long period of time. Poverty further results in low attendance of supportive programmes available to caregivers due to lack of transport and finances ${ }^{35}$. A South African study highlighted that participants from the general public focused more on broader contextual issues such as child kidnapping rather than prominent local problems of poverty and violence, which was realistic when considering the dynamics of the lower resourced communities. This may result from dispirited acceptance of their situation due to the continuous intergenerational cycle of poverty. However, a larger number of people remain cognisant of the more local issues within their communities and therefore request information on protecting their children be incorporated in the stimulation programme ${ }^{27}$.

\section{Macrosystem}

This follows the overarching factors that present itself in the caregivers' practices, such as cultural practices commonly followed. In the Ghana study, ECD facilities were for the dual purpose of educating the child academically and encourage appropriate cultural practices such as respect and social etiquette ${ }^{26}$. Teaching children respect, good behaviour, and morals indicated positive parenting ${ }^{32}$, and opposing behaviour was a negative impression on the caregiver's skills. For example, in the Botswana study, some customs indicated that it was disrespectful for children to play in front of adults ${ }^{28}$. Play is a child's natural engagement and is often done near or with adults, so they can be monitored while playing. Although forming part of their culture, the lack of engagement in play with the children may have an impact on developing the relationships among caregivers as well as providing stimulation during the interaction within such communities. Culture played an additional role in household tasks and self-care management. Engaging in household tasks and selfcare promotes independent, self-reliant adults and further provides an indication of the culture followed ${ }^{25,28}$. This highlights how some cultural practices are more deeply embedded in specific contexts than others and should always be a contributing factor in the approach used.

In South Africa, there are several policies in place to provide support for caregivers and to facilitate appropriate services available for the child ${ }^{39}$. There is a specific criterion that early childhood development facilities should be registered with the provincial government. The policies in place are integral for optimal functioning of facilities and to the benefit of the child and caregiver. This review highlights how the policy requirements are impractical as these strict regulatory guidelines hamper access to early childhood development facilities and are unrealistic in South Africa, which has a vast range of differing communities such as urban, peri-urban and rural communities ${ }^{10}$. Within low resourced communities, access to informal structures is prevalent due to convenience and affordability. The evaluation that these facilities should not be similar to those of different socio-economic levels ${ }^{9}$. The flexibility of these policies could provide a change in accessing these facilities.

The National Integrated Early Childhood Development Plan (2015) further encourages the collaboration with early childhood development facilities, and in conjunction with the South African National Curriculum Framework (2012), future plans for parenting programmes are in place. Yet there is limited communication 
across government sectors to target caregivers to facilitate their understanding of stimulation, learning, engagement in play and how to support their children ${ }^{39}$. The National Integrated Early Childhood Development Plan (20I5) further stipulates the education of positive discipline strategies and to step away from corporal punishment. The public acknowledges that the government plays a role in early childhood development, yet remain unaware of what the role entails ${ }^{29}$. Furthermore, these public respondents further indicated that children had too many rights, limiting their engagement in corporal punishment ${ }^{29}$. The policy initiative attempts to dissolve inappropriate discipline; however, the public's perspectives negate this initiative. Increased awareness of this may promote further positive practices.

\section{LIMITATIONS OF THE STUDY}

Most of the literature reported in this study were qualitative in nature and the perspectives were of the female caregivers. Responses of the male caregivers ${ }^{40}$, grandparents or other family members were limited thus it was challenging for the author to provide a holistic overview of different caregivers' perspectives regarding their role and understanding of early childhood development and stimulation. The inclusion of policies and legislature assisted in understanding what types of governmental support there are available for caregivers and how they impact the caregiver role and practices Policies were only considered from KwaZulu-Natal ${ }^{41}$ and South Africa ${ }^{39}$, not sub-Saharan Africa which limits the scope of the study. The study was conducted by a primary researcher and assisted by research supervisors. The review being completed by one primary researcher may have impacted the researcher bias and rigour of the study which may cause inaccurate interpretations.

\section{CONCLUSION}

Caregivers form a crucial part of the child's ecosystem, yet many caregivers from under resourced contexts may not have the adequate knowledge, skills, understanding, resources or time to facilitate early childhood development. This may result from several factors, such as unawareness of services, poor access and limited intersectoral collaboration. The review shows that stimulation programmes can bridge the gap in early childhood development outcomes; however, several factors such as context and culture must be considered. The findings of this review further indicate the need for a multisectoral approach, which should not be limited to just the ECD facility. Therapists working at a primary healthcare level need to collaborate further with caregivers on matters that are relevant to early childhood development and stimulation and ensure that it is contextually relevant. Additionally, the review indicates that services need to be facilitated locally and not just planned nationally or provincially, to ensure that caregivers of children within the ECD phase benefit from the services available.

\section{ACKNOWLEDGEMENTS}

There are no acknowledgments.

\section{AUTHOR CONTRIBUTIONS}

Zainab Ayob conducted the integrative review and was the primary researcher and author. Deshini Naidoo and Chantal Christopher supervised the study and provided guidance through the conceptualisation, and analysis of the review.

\section{CONFLICTS OF INTEREST DECLARATIONS AND FUNDING}

The authors declare no conflict of interest.

\section{REFERENCES}

I. Bronfenbrenner U. Ecological systems theory. Annals of Child Del. Bronfenbrenner U. Ecological systems theory. Annals of Child Development. 1989;6(I): 187-249.

2. Shelton LG. The Bronfenbrenner Primer: A Guide to Develecology. New York: Routledge; 2019.

3. Pitt C, Luger R, Bullen A, Phillips D, Geiger M. Parents as partners: Building collaborations to support the development of school readiness skills in under-resourced communities. South African Journal of Education. 2013;33(4): I-14. doi:https://doi.org/10.15700/201412171334

4. Onwuegbuzie AJ, Collins KMT, Frels RK. Foreword: Using Bronfenbrenner's ecological systems theory to frame quantitative, qualitative, and mixed research. International Journal of Multiple Research Approaches. 2013;7(I):2-8.

doi:https://doi.org/10.5172/mra.2013.7.1.2

5. Atmore E, Van Niekerk L, Ashley-Cooper M. Challenges Facing Early Childhood Development Sector in South Africa. National Development Agency. 2012;(April):49.

https://www.nda.org.za/assets/resources/CF82442 I-4FA0-4IEEAB69-4DB I0CD0384A/Challenges-facing-ECD-Sector-in-SA-ProfAtmore.pdf

6. UNICEF. UNICEF's Programme Guidance for Early Childhood Development. New York; 2017.

https://sites.unicef.org/earlychildhood/files/FINAL_ECD_Programme_Guidance._September._2017.pdf

7. Hall K, Sambu W, Almeleh C, Mabaso K, Giese S, Proudlock P. South African Early Childhood Review. Cape Town: Children's Institute; 2019.

http://childrencount.uct.ac.za/uploads/publications/SAECR_2019.pdf

8. Krishnan V. Early Child Development: A Conceptual Model. 2010

9. van Niekerk L, Ashley-Cooper M, Atmore E. Effective early childhood development programme options meeting the needs of young South African children. Centre for Early Childhood Development, Cape Town. 2017:295.

10. Budlender D, Motala D, Motala S. Development of a subsidy model for home- and community-based early childhood development services for children 0-5 : Community Agency for Social Enquiry. Human Sciences Research Council. 2010;(February). http://www.hsrc.ac.za/en/research-data/view/4976

I I. Rich EG, Roman N V. Legislative Policies And Culture On Parenting Practices: improving the parent-child relationship in South Africa. Revista de Políticas Públicas. 2019;23(I):389. doi:https://doi.org/10.18764/2 I78-2865.v23n I p389-40 I

12. Albino N, Berry L. Early childhood development services in South Africa: What are the next steps? In: Berry L, Biersteker L, Dawes H, Lake L, Smith C, editors. South African Child Gauge. UCT Children's Institute; 2013. p. 78-8I.

https://open.uct.ac.za/bitstream/handle/I I427/3896/CI_chapters_sachildgauge I3_EcdNextSteps_2013.pdf?sequence = I

13. Lu C, Cuartas J, Fink G, McCoy D, Liu K, Li Z, Daelmans B, Richter L. Inequalities in early childhood care and development in low/middleincome countries: 20I0-20I8. BMJ Global Health. 2020;5(2):p. e0023 |4. doi:https://doi.org/10.1 I36/bmjgh-2020-0023 I4

14. Statistics South Africa. General Household Survey. 2019. http://www.statssa.gov.za/publications/P03 18/P03 I82019.pdf

15. Dawes A, Biersteker L, Girdwood L, Snelling M, Horler J. The Early Learning Programme Outcomes Study Technical Report. Claremont Cape Town; 2020.

doi:http://dx.doi.org/I0.13140/RG.2.2.10297.39528

16. Ebrahim H, Seleti J, Dawes A. Learning begins at birth: Improving 
access to early learning. Cape Town; 2013.

www.childrencount.ci.org.za

17. Baker J. Parent Education Programmes for Early Childhood Development: Reflections of Practitioners. Stellenbosch University; 2015. file://C:/Users/Den/Downloads/baker_parent_2014.pdf

18. Philpott, S.C., 2018. Early Childhood Development: The Disability Policy and its implications for occupational therapists. South African Journal of occupational therapy, 48(3), pp.58-6I. http://dx.doi.org/10.17159/2310-3833/2017/vol48n3a9

19. Baker-Henningham H, López Bóo F. Early Childhood Stimulation Interventions in Developing Countries: A Comprehensive Literature Review. IZA Discussion Paper. 2010:1-73.

doi:https://doi.org/10.1007/s 10273-01 I-1262-2

20. Rao N, Sun J, Wong JMS, Weekes B, Ip P, Shaeffer S, Young M, Bray $M$, Chen E, Lee D. Early childhood development and cognitive development in developing countries: A rigorous literature review. Department for International Development. 20I4;(September): I-100. http://cerc.edu.hku.hk/wp-content/uploads/ECD-review.pdf

21. Homan, A., 2018. Towards occupational enablement: experiences of the ECD practitioners regarding the crosstrainer programme (Masters dissertation, University of the Free State).

22. Whittemore R, Knafl K. The integrative review: Updated methodology. Journal of Advanced Nursing. 2005;52(5):546-553. doi: https://doi.org/I0.1 I I I/j. I365-2648.2005.0362I.x

23. Peters MD, Godfrey C, Mclnerney P, Baldini Soares C, Khalil H, Parker D. Chapter II: Scoping reviews - JBI Wiki. In: Aromataris E, Munn Z, editors. Joanna Briggs Institute Reviewer's Manual. The Joanna Briggs Institute; 2017.

24. Creswell JW. Research Design: Qualitative, Quantitative, and Mixed Mehtods Approaches. 4th ed. SAGE Publications; 2014.

25. Balton $S$, Uys $K$, Alant E. Family-based activity settings of children in a low-income African context. African Journal of Disability. 2019;8: I-14. doi:https://doi.org/10.4102/ajod.v8i0.364

26. Kabay S, Wolf S, Yoshikawa $H$. "So that his mind will open": Parental perceptions of early childhood education in urbanizing Ghana. International Journal of Educational Development. 2017;57(January):44-53. doi:https://doi.org/10.1016/j.ijedudev.2017.08.013

27. Lachman JM, Sherr LT, Cluver L, Ward CL, Hutchings J, Gardner F. Integrating Evidence and Context to Develop a Parenting Program for Low-Income Families in South Africa. Journal of Child and Family Studies. 2016;25(7):2337-2352.

doi:https://doi.org/10.1007/s10826-016-0389-6

28. Tsamaase M, Harkness S, Super CM. Grandmothers' Developmental Expectations for Early Childhood in Botswana. New Directions for Child and Adolescent Development. 2020;2020(I70):93-II 2. doi:https://doi.org/10.1002/cad.20335

29. Richter LM, Tomlinson M, Watt K, Hunt X, Lindland EH. Early means early: understanding popular understandings of early childhood development in South Africa. Early Years. 2019;39(3):295-309. doi:https://doi.org/10.1080/09575|46.2019.1613346

30. Wolf S. "Me I don't really discuss anything with them": Parent and teacher perceptions of early childhood education and parent-teacher relationships in Ghana. International Journal of Educational Research. 2020;99(September 2019): 101525.

doi:https://doi.org/10.1016/j.ijer.2019.101525

31. Berry, Lizette; Malek E. Caring for children: Relationships matter. Cape Town; 2017. https://bettercarenetwork.org/sites/default/files/ Caring for Children.pdf

32. Boothby N, Mugumya F, Ritterbusch AE, Wanican J, Ahabwe C, Pizatella AD, Busi S, Meyer S. Ugandan households : A Study of parenting practices in three districts. Child Abuse \& Neglect.
2017;67:157-173. doi: https://doi.org/10.1016/j.chiabu.2017.02.010

33. Worthman CM, Tomlinson M, Rotheram-Borus MJ. When can parents most influence their child's development? Expert knowledge and perceived local realities. Social Science and Medicine. 2016; 154:62 69. doi:https://doi.org/10.1016/j.socscimed.2016.02.040

34. Neudorf K, Thurman T, Taylor TM. Interventions promoting early childhood development in South Africa. Tulane University School of Public Health and Tropical Medicine,; $201 \mathrm{I}$.

https://hvc-tulane.org/interventions-promoting-early-childhooddevelopment-in-south-africa/

35. Ramugondo E, Ferreira A, Chung D, Cordier R. Research Article A Feasibility RCT Evaluating a Play-Informed, Caregiver-Implemented , Home-Based Intervention to Improve the Play of Children Who Are HIV Positive. Occupational Therapy International. 2018;(Article ID 3652529): I 5 pages. doi:https://doi.org/I0. I I55/2018/3652529

36. The Project Preparation Trust of KwaZulu-Natal. Informal settlements: Informal early childhood development centres. 2014.

http://thehda.co.za/pdf/uploads/multimedia/ISU_Guidelines_Informal_Early_Childhood_Development_Centres_in_Informal_Settlements-ilovepdf-compressed-compressed.pdf

37. Munnik E, Smith M. Contextualising school readiness in south africa: Stakeholders' perspectives. South African Journal of Childhood Education. 20I9;9(I):I-I3. doi:https://doi.org/I0.4I02/sajce.v9il.680

38. Ebrahim $\mathrm{H}$, Irvine M. The South African National Curriculum Framework for children from Birth to Four. 2012.

http://www.education.gov.za/Portals/O/Documents/Publications/ National Curriculum Framework for children from birth to four. pdf?ver =20 I 4- I2-04- |44326-000

39. Department of Social Development. National Integrated Early Childhood Development Policy 2015. 2015: I-140. doi:https://doi.org/10.1007/s00 I I 2-008-1824-6

40. Basil PT, Ndijuye LG. Is Fathers' Involvement in Young Children's Development and Learning in the Early Years Important? Experiences from the Caregivers in Tanzania. Global Education Review. 2019;6(I):63-74.

4I. eThekwini Municipality. eThekwini Municipality Early Childhood Development Launch. 2015. http://www.durban.gov.za/City_Services/ DCM - Support Services/Documents/ECD LAUNCH ARTICLE edited.pdf

Corresponding Author

*Zainab Ayob

Email: zainabayob@gmail.com 